Article

\title{
University Student Mental Well-Being during COVID-19 Outbreak: What Are the Relationships between Information Seeking, Perceived Risk and Personal Resources Related to the Academic Context?
}

\author{
Vincenza Capone * $*$, Daniela Caso $₫$, Anna Rosa Donizzetti and Fortuna Procentese $\mathbb{}$ \\ Department of Humanities, University of Naples Federico II, 80100 Naples, Italy; daniela.caso@unina.it (D.C.); \\ annarosa.donizzetti@unina.it (A.R.D.); fortuna.procentese@unina.it (F.P.) \\ * Correspondence: vincenza.capone@unina.it; Tel.: +39-0812-535639
}

Received: 30 July 2020; Accepted: 25 August 2020; Published: 28 August 2020

check for updates

\begin{abstract}
In light of rising concern about the coronavirus pandemic crisis, a growing number of universities across the world have either postponed or canceled all campus and other activities. This posed new challenges for university students. Based on the classification proposed in the Mental Health Continuum model by Keyes, the aims were to estimate university students' prevalence of mental health during lookdown outbreak, and to examine the associations between mental health and, respectively, academic stress, self-efficacy, satisfaction for degree course, locus of control, COVID-19 risk perception, taking into account the level of information seeking about pandemic. Overall, 1124 Italian university students completed a self-report questionnaire. Data were analyzed using descriptive and correlational analyses. Results showed that $22.3 \%$ of participants were flourishing, and levels of mental well-being appeared in line with normative values in young Italian adults; levels of academic stress were not significantly higher than those found in other student samples before the COVID-19 outbreak. Students with high levels of information seeking presented higher levels of well-being and risk perception. Results could be considered useful to realize training pathways, to help the university students to improve their well-being, post-pandemic.
\end{abstract}

Keywords: university students; mental well-being; risk perception; COVID-19 pandemic; self-efficacy; locus of control; sense of belonging

\section{Introduction}

Since the end of December 2019 and January 2020, researchers have identified a particular coronavirus responsible for a disease named COVID-19 [1] and, since March 11th, the World Health Organization assessed that COVID-19 could be characterized as a pandemic. Italy has been the second worst affected country after China.

In light of rising concern about the current COVID-19 pandemic, a growing number of universities across the world have either postponed or canceled all campus and other activities. The rapid spread of COVID-19 in Italy led the government to take rigid measures to contain its propagation. Among these measures, one in particular involved students: the suspension of teaching in attendance [2]. This unforeseen crisis and the unprecedentedly stringent precaution measures, such as strict quarantines and schools' closures, have remarkably changed people's lives and put their mental health and psychosocial functioning at risk. Universities had to move rapidly to transition various courses and programs from face-to-face to online delivery model. This, therefore, posed new challenges for students, such as the development of different studying methods, more autonomous management of the studies path, a new bureaucracy, and widespread uncertainty. Uncertainty is accompanied by a continuous 
increase in information on the severity of the pandemic. Therefore, to study the subjective factors implied in such reactions is of much relevance for effectively sensitize the university stakeholders and identify high-risk targets.

In the context of higher education, mental well-being has been associated with central outcomes, such as educational aspirations, academic engagement, academic achievement, and dropout [3]. After all, in younger people, well-being grows thanks to positive experiences with peers and significant adults in different settings [4]. So, university plays a central role in youths' lives: the need for belonging, relationship with colleagues and acceptance take on special importance for it. Well-being indicators have additive value in predicting the longitudinal growth or declines of students' academic skill development, and school attendance [5]. Furthermore, universities influence well-being among students also through the policies and practices they adopt, the values they express, the sense of belonging, and the possibilities they offer to students in terms of spaces and events [6]. However, the current understanding of how an outbreak influences students' mental well-being is incomplete.

The study aims to answer several questions: how will university students face their study path in this delicate moment of a global health emergency? How will their perception of risk affect individual and academic well-being? What factors can promote their well-being? What is the role of information seeking about pandemic?

Recent research investigating the psychological impact of the current pandemic has considered various aspects of mental disease, like common mental health disorders, ranging from anxiety, depression, sleep disorders, and other symptoms $[7,8]$. In our knowledge, no study has adopted a positive prospecting yet, by employing the Mental Health Continuum Model [1] to assess university students' well-being during this international emergency.

In this aim, this paper has the goal of focusing on Italian university students' mental well-being during the COVID-19 pandemic. In particular, we will employ the Mental Health Continuum model [4], to estimate participants' well-being and consider the impact of several variables concerning information seeking and personal and collective risk perceptions, along with constructs regarding psychosocial assets in the university context, like sense of belonging, students' efficacy beliefs, satisfaction for degree course, locus of control, and academic stress. Identifying these factors is critically important, as they inform policies and interventions aimed at protecting students' well-being, and promote adequate career skills in the era of pandemics, but also in the later stages.

\section{Theoretical Background}

University life is notorious for challenging students' levels of well-being, demanding that they manage competing for academic and social goals, as well as their efficacy beliefs to both success and disappointment. The COVID-19 outbreak has disrupted their lives. The worldwide rapid increase of infected cases has created a sense of uncertainty and anxiety about what is going to happen. This stress may lead to unfavorable effects on the learning and mental well-being of students [9]. Furthermore, the transition from face-to face teaching to online delivery could have a severe impact on students' career and well-being.

In studying mental well-being, some researchers have portrayed it as an individual's pursuit of pleasure, satisfaction with life, experience of positive affect, and absence of negative affect [10]. Others have theorized well-being as more related to one's sense of purpose in life, self-acceptance, fulfillment of potential, and feelings of mastery [11,12]. In our study, we included all these views, following the Mental Health Continuum model [13].

The mental health continuum consists of complete and incomplete mental health. People with complete mental health are flourishing in life, with high levels of well-being. To be flourishing, then, is to be filled with positive emotion, and to be functioning well psychologically and socially. People with incomplete mental health are languishing in life with low well-being. Thus, languishing may be conceived of as emptiness and stagnation, constituting a life of quiet despair that parallels accounts of individuals who describe themselves and life as "hollow", "empty", "a shell", and "avoid" [14] p. 607. 
Keyes [4,14] affirmed that a diagnosis of mental health is made when people show high levels of at least one symptom of hedonia and on just over half of the eudaimonia symptoms.

When people mature a complete consciousness of the characteristics and consequences of the critical situation, and assume a better responsible position in their behaviors and risk management, they reach a better and positive approach to the situation $[15,16]$. The epidemic has received widespread media attention globally, and is subjected to much discussion on social media, contributing to the types of information about the virus, and influencing the perception of risk among people. Exposition to different types of information sources available nowadays is considered a crucial factor that impacts people's attitudes and opinions relating to health in general [17]. For example, a survey run in Saudi Arabia during the spread of Middle East Respiratory Syndrome in 2014 showed that the internet was the most commonly used source of information and the most endorsed channel for a MERS awareness campaign, although this data was age-sensible, with younger people tending to prefer the internet to other sources of information more [18].

Social media's role in diffusing health-related information and behaviors is non-negligible, as they offer users the opportunity to communicate, stay in touch, and interact with others $[19,20]$. Moreover, during the lockdown in Italy, people increased their use of digital media [8]. Scholars have identified the importance of considering, in a conceptual framework of emergencies, management of the impact of information source and risk communication on people's well-being during different kinds of calamity [21]. A recent work by Liu [22] highlighted that COVID-19 information seeking through different types of digital media was a salient parameter that encouraged people to practice preventive behaviors either directly or indirectly. Seeking information could produce health-related thoughts and concerns given the dangerous infections [22], operationalized in this study as risk perceptions. On the other hand, adopt information-processing strategies during COVID-19 might help individuals to improve their well-being.

Risk perception as one of the most relevant variables in determining individuals' responses to global pandemic disease [23]. It is a cognitive process involved in various daily activities and responsible for steering people's behavior when they have to take decisions involving potential risks. Risk perception covers multiple dimensions, such as, for example, immediate and future consequences and their implications on both a rational and objective and an emotional and subjective level [24]. Assessing this variable is particularly important during a global pandemic, because it is well-known that the risk perception can influence protective behaviors [25-29]. Furthermore, suppose the information provided is inadequate. In that case, it can result in leading people to take inappropriate protective actions [30], such as non-compliance with the public health authorities' recommendations or, on the opposite pole, negative emotional responses and unwarranted concerns about contact with other people [31]. Moreover, risk perception can vary from age [32]. A recent survey examining this variable in German population showed that people are highly worried about COVID-19 in general, but less afraid of being infected, and that older people significantly think they are less likely to be infected in general, or in the near future than do younger [33]. In this light, it would be interesting to determine the impact of this construct on students' well-being during the pandemic.

The locus of control referring to health [34-36] is a construct often employed for understanding and predicting health behaviors. It relates to the representations that individuals have of the causes underlying their well-being and diseases. According to previous research, those who have internal health locus of control tend to attribute greater importance to their will, commitment, and responsibility [37-39]. Furthermore, individuals with an internal health locus of control are more sensitive to health-related messages, know their condition better and try to improve it, often resulting in being less susceptible to physical and psychological dysfunctions [40], leading to high levels of well-being [41].

Some recent studies have investigated this construct in different populations during the COVID-19 pandemic, showing interesting results. For instance, Dunning and Pownall [42] investigated the link between perceived risk of being personally infected and health locus of control in a British sample. 
Findings highlighted that participants perceiving low risk made more dispositional attributions (i.e., age or personal hygiene practices), while higher risk was associated with situational attributions (i.e., government decisions or other people's hygiene). Alongside these constructs, it is also worth investigating how the COVID-19 emergency could affect students' career skills. For students of all levels and degrees, the suspension of teaching in attendance was a radical and suddenly change in the way of organizing their academic activities and studying. It is urgent to estimate the impact on students' academic efficacy beliefs, wellbeing and the related possible negative outcomes, such as an increase in their academic stress level.

Several studies have shown that the management of the academic path by university students is complex and can be a source of stress, even in a non-emergency situation [43]. The cognitivetransactional model [44] p. 19 defines stress as "a transaction between the person and the environment, in which the individual assesses the situation as exceeding his resources and such as to put danger to his well-being". In particular, in dealing with the typical problems that may arise in the academic environment, stress can represent a natural and necessary reaction for university students to survive in this context, where factors such as work overload, group projects, competitiveness, lack of technological resources, lack of supervision or inadequate organization of time, can produce a condition of chronic stress [45]. The consequences of stress include negative academic outcomes, reduced cognitive abilities, coping problems and incompleteness of university studies [46]. Research that analyzed the relationship between stress and performance in university students reported that stress affects academic results [47]. As far as health consequences are concerned, academic stress is associated with physical and psychological symptoms, such as impaired appetite, sleep disturbances, headaches and increased heart rate [48,49]. The correlation between academic stress and wellbeing is not surprising [50]. Stressful stimulus can, therefore, interfere with academic preparation, concentration and performance [51]. The primary reported sources for academic stress were anxiety related to exams [51] and the university's organizational structure, like changes in scheduled exams, changes in the due dates of specific tasks and projects, and cancellation of lessons [52]. In this light, it is realistic to expect an impact of the COVID-19 emergency and the social distancing measures on university students' academic stress and well-being.

While facing a stressful situation, people can rely on their personal resources to cope with the difficulties. On the subject, self-efficacy is considered as being capable of moderating the relationship between stressor and strain in the discrepancy between requests and resources (including in the academic sphere) [53]. It is also defined as one of the protective factors for academic achievement. Self-efficacy is the major component of the individual's ability to act successfully, referred to as "beliefs in one's capabilities to organize and execute the courses of action required producing given attainments" [54] p. 3. Bandura [55] has argued that the pursuit of meaningful goals and their attainment are essential components of adaptive self-regulation that contribute positively to overall health and well-being. Furthermore, several studies [56-59] have demonstrated the moderating role of academic self-efficacy, defined as an individuals' conviction that they can successfully perform given academic tasks, on awareness and the adoption of effective strategies related to academic commitment and in the evaluation of problems to be solved. For the reasons mentioned above, the impact of this variable on students' well-being during the national health emergency will also be investigated.

Moreover, sense of belonging, as a dimension of sense of community, is considered a core construct, capable of orienting interventions aimed at increasing the well-being within communities [60]. In a study conducted on a sample of college students in three different countries (USA, Italy, and Iran), town sense of community influenced well-being in all the samples [61]. In recent Italian studies [62,63], the relationship between well-being and sense of belonging was particularly noteworthy, in school context.

At the same time, high levels of satisfaction with one's university degree and the study and occupational prospects that it offers represent an indication of how the educational context might impact how students can become successful, predicting also their well-being. We affirm that satisfaction 
with one's university course serves also as a contextual boundary factor that may enhance the process in which students use their academic competencies to become more successful [64].

\section{Aims and Hypothesis}

To the best of our knowledge, so far, no study has targeted mental well-being in Keyes [1] perspective among university students, even during the COVID pandemic. The present research focused on positive mental health of university students within the Mental Health Continuum model [4] and during the COVID-19 emergency outbreak. In this regard, the study's goal is to empirically test the Mental Health Continuum using Italian data based on a sample of university students. Specific aims of the study were to estimate the prevalence of flourishing and languishing among participants and examine the incidence of some academic variables (students' self-efficacy, satisfaction and university sense of belonging), new media information seeking about COVID-19, internal locus of control and COVID-19 personal and collective risk perceptions in the Mental Health Continuum Model categories. A further aim was to explore the association between student mental well-being and variables related to psychosocial assets in university context and pandemic connected risk, also taking into account the levels of information seeking.

Based on the above-mentioned empirical results (see introduction), the following hypotheses were advanced:

Hypothesis 1. We expected H1a: that the diagnostic categories in flourishing, moderately healthy and languishing could be applied on university student populations; and H1b that the diagnostic categories in the categorical assessment of mental well-being, to distinguish levels of self-efficacy, satisfaction, sense of belonging, information seeking effect, internal locus of control, risk perception and academic stress between flourishing, moderately mentally healthy, and languishing university students.

Hypothesis 2. A significantly higher level of satisfaction, sense of belonging, self-efficacy, as well as personal and collective risk perceptions were expected in students with higher levels of information seeking.

Hypothesis 3. We expected that mental well-being, and its sub dimensions, were negatively correlated with measures of academic stress, and risk perceptions, and positively and significantly correlated with self-efficacy, satisfaction, sense of belonging, information seeking, internal locus of control.

\section{Materials and Methods}

\subsection{Participants and Procedure of Recruitment}

Participants consisted of 1124 Italian university students (79.6\% females, 20.4\% males), aged from 18 to 63 years $(\mathrm{M}=23.8, \mathrm{SD}=4.4)$. Overall, $54.5 \%$ of the participants were bachelor's degrees, $30.7 \%$ were magistral degrees, $14.4 \%$ were degree in one cycle, and $0.4 \%$ were higher education (master and specialization). Moreover, $73 \%$ of participants declare that in the territory where they live there are cases of people declared positive for COVID-19, and 9.5\% say they know them personally.

Participants were recruited from 10 to 27 March 2020 during the coronavirus outbreak. All data were collected with self-report questionnaires using an internet-based survey [65], implemented on the Google Forms platform. Participation in the study was voluntary and anonymous. Participants gave consent to participate on the first page of the survey, which took approximately $30 \mathrm{~min}$ to complete.

This study has been approved by the Institutional Review Board of University of Naples Federico II, Department of Humanities. 


\subsection{Measures and Analyses}

Making use of a quantitative methodology, a questionnaire containing various measures was specifically designed.

Social media information seeking. Participants were asked to indicate how often they were interested in news and information on COVID-19 from social media during the past week. Scale ranging: $1=$ rarely, 2 = fairly frequently, 3 = very frequently. Because of the less proportion of rarely, we recoded social media exposure into "sometimes" (rarely and fairly frequently) and "frequently" (very frequently).

Internal Health Locus of Control scale (IHLCS) $[35,36]$. The IHLCS, for the measurement of the internal orientation of locus of control related to health, is composed of three dimensions (e.g., of item: "I am the only one responsible for my health"; $\alpha=0.81$ ). The IHLCS is made up of 8 items, with an answering range of 5 points (from $1=$ strongly disagree to $5=$ strongly agree).

Personal and Collective Risk perception. The perception of personal and collective risk was detected through two ad hoc items: What is your level of knowledge of the possible risks associated with COVID-19 contagion? and To what extent, in your opinion, are the risks associated with COVID-19 contagion known and known to the scientific community?. The participants responded on 7-point Likert scales "they do not scare me at all/not at all risky" (1) to "they scare me a lot/extremely risky".

Student Self-efficacy Scale [56,66]. Student self-efficacy was detected through 6 items (e.g., of item: "I think I'm a good student") assessed on a Likert scale in 7 points ranging from 1 = very much in disagreement to $7=$ very much in agreement. Cronbach's alpha was 0.81 .

Satisfaction for the course degree. The course degree's satisfaction was detected through one item: I am satisfied with my course of study. The participants responded on a 7-point Likert scale: completely disagree (1) to completely agree (7).

Sense of belonging to the University [67]. Sense of belonging was detected through 3 items (e.g., I feel I belong to my university) assessed on 4 points Likert scale, ranging from $1=$ strongly disagree to strongly agree (4). Cronbach's alpha was 0.83 .

Perception of Academic Stress Scale (PAS) [68]. Academic stress was assessed using the 18 items that are divided into three subscales representing different sources of academic stress: stresses related to academic expectations (e.g., of item: "The unrealistic expectations of my parents stress me out"; $\alpha=0.61$ ), stresses related to faculty work and examinations (e.g., of item: "I believe that the amount of work assignment is too much"; $\alpha=0.79)$, and stresses related to students' academic self-perceptions (e.g., of item: "I think that my worry about examinations is weakness of character"; $\alpha=0.75$ ). The participants responded on a 5-point Likert scale: strongly disagree (1) to strongly agree (5).

Mental Health Continuum-Short Form (MHC-SF) [12]. The MHC-SF consists of 14 items on 6-point scales, ranging from $0=$ never to $5=$ every day. It measures the degree of emotional well-being (e.g., of item: "During the past month, how often did you feel happy"; $\alpha=0.80$ ), social well-being (e.g., of item: "During the past month, how often did you feel that you belonged to a community"; $\alpha=0.80$ ), and psychological well-being (e.g., of item: "During the past month, how often did you feel that you had warm and trusting relationships with others"; $\alpha=0.88$ ). Cronbach's alpha for MHC-SF was 0.90 .

Participants were also asked to report general demographic information such as gender and age. Survey data were then entered into SPSS 22.0 databases and checked/verified by project staff for accuracy.

\section{Results}

\subsection{Assessment of the Italian MHC-SF in University Students}

The mean for the total MHC-SF score was 3.53 (SD = 1.04; range: 1-5); the mean for Emotional well-being subscales was $3.63(\mathrm{SD}=1.26)$, for the Social well-being subscale was $2.84(\mathrm{SD}=1.20)$ and $4.05(\mathrm{SD}=1.24)$ for the Psychological well-being subscale. 
The categorical diagnosis using the MHC-SF by Keyes [69] was applied to the data, to obtain estimates of the students' prevalence of the mental well-being categories. Adults with complete mental well-being were flourishing in life with high levels of well-being [14]. To be flourishing, individuals must report that they experience "everyday" or "almost every day" at least seven of the symptoms, where one of the symptoms is from the hedonic cluster (i.e., happy, interested in life, or satisfied). Adults with incomplete mental health are languishing in life with low well-being. To be languishing, individuals must report that they "never" or "only once or twice" experienced at least seven of the symptoms, where one of the symptoms is from the hedonic cluster. Individuals who do not fit the criteria for flourishing or languishing are categorized as moderately mentally healthy.

Based on these diagnostic criteria, the data reveal that $17.5 \%$ of the sample were languishing, $52.9 \%$ were moderately mentally healthy, and $22.3 \%$ were flourishing (because of missing data in one or two items of MHC-SF, 7.3\% of respondents were excluded). Flourishing and Moderates have an average age of about 24 years (Flourishing: $\mathrm{M}=24.1$; $\mathrm{DS}=4.89$; Moderate: $\mathrm{M}=24.0$; $\mathrm{DS}=4.7$ ), while Languishing of about 23 and a half years $(M=23.4$; $D S=3.2)$. In addition, over half of women $(56.9 \%)$ and men $(57.3 \%)$ belong to the Moderate category; $27.0 \%$ of men and $23.4 \%$ of women belong to the category of Flourishing; and finally, $19.8 \%$ of women and $15.6 \%$ of men have been classified as Languishing. A hierarchical loglinear analysis and chi-square tests was then performed to investigate the association among gender and age, and categorical diagnosis of mental health. No significant results emerged. Table 1 presents the mean levels of the scales reflecting locus of control, risk perception, academic stress, student self-efficacy, satisfaction for the course degree and sense of belonging to university by level of mental well-being. Pairwise contrasts using the Tukey Honestly Significant Difference Test were used to test mean psychosocial assets by diagnosis of mental well-being.

All psychological measures, except for academic stress, were higher in flourishing individuals than in those who were moderately mentally healthy or languishing. 
Table 1. Descriptive analyses and ANOVA: Internal Health Locus of Control, Risk Perceptions, Academic Stress, Student Self-efficacy, Satisfaction for the course degree and Sense of belonging to University by categorical diagnosis of mental well-being.

\begin{tabular}{|c|c|c|c|c|c|c|c|c|c|}
\hline & \multirow[b]{2}{*}{ Range } & \multirow[b]{2}{*}{$\mathbf{M}$} & \multirow[b]{2}{*}{ SD } & \multicolumn{6}{|c|}{ Categorical Diagnosis of Mental Well-Being } \\
\hline & & & & $\begin{array}{l}\text { Languishing } \\
\quad \mathbf{N}=197\end{array}$ & $\begin{array}{c}\text { Moderate } \\
\mathrm{N}=595\end{array}$ & $\begin{array}{c}\text { Flourishing } \\
\mathrm{N}=251\end{array}$ & $F$ & $p$ & $\eta^{2}$ \\
\hline Internal Health Locus of Control & $1-5$ & 3.98 & 0.61 & 3.79 & 3.97 & 4.18 & 23.50 & 0.00 & 0.04 \\
\hline Collective risk perception & $1-7$ & 3.03 & 1.33 & 5.97 & 6.24 & 6.39 & 9.45 & 0.00 & 0.02 \\
\hline Personal risk perception & $1-7$ & 4.02 & 1.10 & 5.07 & 5.38 & 5.26 & 3.35 & 0.04 & 0.01 \\
\hline Academic Stress & $1-5$ & 2.78 & 0.67 & 3.12 & 2.78 & 2.47 & 57.00 & 0.00 & 0.10 \\
\hline Stress academic expectations & $1-5$ & 2.32 & 0.83 & 2.55 & 2.29 & 2.17 & 12.43 & 0.00 & 0.02 \\
\hline Stress_faculty work and examinations & $1-5$ & 2.86 & 0.77 & 3.15 & 2.85 & 2.61 & 29.45 & 0.00 & 0.05 \\
\hline Stress_students' academic self-perceptions & $1-5$ & 2.98 & 0.81 & 3.44 & 3.01 & 2.50 & 86.49 & 0.00 & 0.14 \\
\hline Student Self-efficacy & $1-7$ & 3.91 & 0.71 & 3.39 & 3.93 & 4.30 & 110.63 & 0.00 & 0.18 \\
\hline Satisfaction for the course degree & $1-7$ & 5.30 & 1.58 & 4.56 & 5.32 & 5.90 & 42.65 & 0.00 & 0.08 \\
\hline Sense of belonging to University & $1-4$ & 3.08 & 0.68 & 2.78 & 3.08 & 3.32 & 37.21 & 0.00 & 0.07 \\
\hline
\end{tabular}

All $\mathrm{df}=2,1040$, and subscripts normal, italic and bold show graphically the results of the Tukey test. 


\subsection{Social Media Information Seeking and Psychological Variables}

Participants were asked to indicate how often during the past week they were interested in news and information on COVID-19 from social media. From the descriptive analyses carried out in relation to the psychological variables considered, it emerged that the participants have medium-high levels of: Psychological ( $\mathrm{M}=4.05 ; \mathrm{DS}=1.24)$ and Emotional well-being $(\mathrm{M}=3.63 ; \mathrm{DS}=1.26)$, Internal Health Locus of Control $(M=3.98 ; D S=0.61)$, Satisfaction for the course degree $(M=5.30 ; D S=1.53)$, Collective Risk Perception ( $M=6.22$; $D S=1.03$ ) and Sense of belonging to University $(M=3.08$; $D S=0.68)$. The existence of differences between the students was verified on the basis of the different social media information seeking. The ANOVA (Table 2) showed that those who have been most frequently exposed to social media have higher levels of well-being $\left(\mathrm{M}_{\mathrm{S}}=3.42\right.$ vs. $\mathrm{M}_{\mathrm{F}}=3.60 ; \mathrm{F}_{(1,1122)}=8.15$, $\left.p<0.004 ; \eta^{2}=0.01\right)$, and in particular social $\left(\mathrm{M}_{\mathrm{S}}=2.65\right.$ vs. $\mathrm{M}_{\mathrm{F}}=2.96 ; \mathrm{F}_{(1,1122)}=18.22, p<0.000$; $\left.\eta^{2}=0.02\right)$ and psychological $\left(\mathrm{M}_{\mathrm{S}}=3.94\right.$ vs. $\left.\mathrm{M}_{\mathrm{F}}=4.12 ; \mathrm{F}_{(1,1122)}=5.18, p<0.02 ; \eta^{2}=0.00\right)$ well-being, than students with lower information seeking. Collective $\left(\mathrm{M}_{\mathrm{S}}=5.99\right.$ vs. $\mathrm{M}_{\mathrm{F}}=6.37 ; \mathrm{F}_{(1,1122)}=38.75$, $\left.p<0.000 ; \eta^{2}=0.03\right)$ and Personal $\left(\mathrm{M}_{\mathrm{S}}=4.82\right.$ vs. $\left.\mathrm{M}_{\mathrm{F}}=5.57 ; \mathrm{F}_{(1,1122)}=69.91, p<0.000 ; \eta^{2}=0.06\right)$ levels of perception of risk are higher for who have been most frequently exposed to social media information about the pandemic.

\subsection{Correlations}

Zero-order correlations between the measures are shown in Table 3. Results indicate that well-being is negatively correlated with Academic Stress and its subscales, while it is positively correlated with all other measures. 
Table 2. Descriptive analyses and ANOVA: Internal Health Locus of Control, Risk Perceptions, Academic Stress, Student Self-efficacy, Satisfaction for the course degree and Sense of belonging to University by Social media information seeking.

\begin{tabular}{|c|c|c|c|c|c|c|c|c|}
\hline & \multirow[b]{2}{*}{ Range } & \multirow[b]{2}{*}{$\mathbf{M}$} & \multirow[b]{2}{*}{ SD } & \multicolumn{5}{|c|}{ Social Media Information Seeking } \\
\hline & & & & $\begin{array}{l}\text { Sometimes } \\
N=433\end{array}$ & $\begin{array}{c}\text { Frequently } \\
N=691\end{array}$ & $F$ & $p$ & $\eta^{2}$ \\
\hline Well-being & $1-5$ & 3.53 & 1.04 & 3.42 & 3.60 & 8.15 & 0.004 & 0.01 \\
\hline Emotional well-being & $1-5$ & 3.63 & 1.26 & 3.64 & 3.62 & 0.03 & 0.85 & 0.00 \\
\hline Social well-being & $1-5$ & 2.84 & 1.20 & 2.65 & 2.96 & 18.22 & 0.000 & 0.02 \\
\hline Psychological well-being & $1-5$ & 4.05 & 1.24 & 3.94 & 4.12 & 5.18 & 0.02 & 0.00 \\
\hline Internal Health Locus of Control & $1-5$ & 3.98 & 0.61 & 4.02 & 3.96 & 2.48 & 0.12 & 0.00 \\
\hline Collective risk perception & $1-7$ & 6.22 & 1.03 & 5.99 & 6.37 & 38.75 & 0.000 & 0.03 \\
\hline Personal risk perception & $1-7$ & 5.28 & 1.51 & 4.82 & 5.57 & 69.91 & 0.000 & 0.06 \\
\hline Academic Stress & $1-5$ & 2.78 & 0.67 & 2.79 & 2.77 & 0.13 & 0.72 & 0.00 \\
\hline Stress_academic expectations & $1-5$ & 2.32 & 0.83 & 2.35 & 2.31 & 0.69 & 0.41 & 0.00 \\
\hline Stress_faculty work and examinations & $1-5$ & 2.86 & 0.77 & 2.85 & 2.86 & 0.11 & 0.74 & 0.00 \\
\hline Stress_students' academic self-perceptions & $1-5$ & 2.98 & 0.81 & 3.00 & 2.96 & 0.54 & 0.46 & 0.00 \\
\hline Student Self-efficacy & $1-7$ & 3.91 & 0.71 & 3.89 & 3.92 & 0.36 & 0.55 & 0.00 \\
\hline Satisfaction for the course degree & $1-7$ & 5.30 & 1.58 & 5.34 & 5.28 & 0.39 & 0.54 & 0.00 \\
\hline Sense of belonging to University & $1-4$ & 3.08 & 0.68 & 3.05 & 3.09 & 0.76 & 0.38 & 0.00 \\
\hline
\end{tabular}


Table 3. Correlations between the variables included in the study.

\begin{tabular}{|c|c|c|c|c|c|c|c|c|c|c|c|c|c|c|c|}
\hline & 1 & 2 & 3 & 4 & 5 & 6 & 7 & 8 & 9 & 10 & 11 & 12 & 13 & 14 & 15 \\
\hline 1. Well-being & 1 & & & & & & & & & & & & & & \\
\hline 2. Emotional well-being & $0.80 * *$ & 1 & & & & & & & & & & & & & \\
\hline 3. Social well-being & $0.81 * *$ & 0.50 ** & 1 & & & & & & & & & & & & \\
\hline 4. Psychological well-being & $0.90 * *$ & $0.67^{* *}$ & $0.54 * *$ & 1 & & & & & & & & & & & \\
\hline 5. Information seeking & $0.09 * *$ & -0.01 & $0.13 * *$ & $0.08 *$ & 1 & & & & & & & & & & \\
\hline $\begin{array}{l}\text { 6. Internal Health Locus of } \\
\text { Control }\end{array}$ & $0.24^{* *}$ & $0.17^{* *}$ & $0.20^{* *}$ & $0.24^{* *}$ & -0.05 & 1 & & & & & & & & & \\
\hline 7. Collective risk perception & $0.14^{* *}$ & 0.06 * & $0.15^{* *}$ & $0.13^{* *}$ & $0.20 * *$ & 0.00 & 1 & & & & & & & & \\
\hline 8. Personal risk perception & $0.07 *$ & -0.04 & $0.14^{* *}$ & 0.05 & $0.27 * *$ & -0.02 & $0.50 * *$ & 1 & & & & & & & \\
\hline 9. Academic Stress & $-0.31^{* *}$ & $-0.30^{* *}$ & $-0.17^{* *}$ & $-0.32 * *$ & -0.01 & $-0.10^{* *}$ & -0.02 & 0.02 & 1 & & & & & & \\
\hline $\begin{array}{l}\text { 10. Stress_academic } \\
\text { expectations }\end{array}$ & $-0.13^{* *}$ & $-0.14^{* *}$ & -0.02 & $-0.17^{* *}$ & -0.013 & -0.03 & -0.02 & -0.02 & $0.75^{* *}$ & 1 & & & & & \\
\hline $\begin{array}{l}\text { 11. Stress faculty work and } \\
\text { examinations }\end{array}$ & $-0.22 * *$ & $-0.21^{* *}$ & $-0.13 * *$ & $-0.21^{* *}$ & 0.01 & $-0.08 * *$ & 0.01 & 0.04 & $0.89^{* *}$ & $0.57^{* *}$ & 1 & & & & \\
\hline $\begin{array}{l}\text { 12. Stress_students' academic } \\
\text { self-perceptions }\end{array}$ & $-0.40^{* *}$ & $-0.38^{* *}$ & $-0.24^{* *}$ & $-0.40^{* *}$ & -0.03 & $-0.11^{* *}$ & -0.04 & 0.02 & $0.81^{* *}$ & $0.45^{* *}$ & $0.54^{* *}$ & 1 & & & \\
\hline 13. Student Self-efficacy & $0.46^{* *}$ & $0.37^{* *}$ & $0.32 * *$ & $0.46^{* *}$ & 0.03 & $0.19^{* *}$ & $0.09 * *$ & 0.07 * & $-0.56^{* *}$ & $-0.36^{* *}$ & $-0.44^{* *}$ & $-0.58 * *$ & 1 & & \\
\hline $\begin{array}{l}\text { 14. Satisfaction for the course } \\
\text { degree }\end{array}$ & $0.29 * *$ & $0.25^{* *}$ & $0.21^{* *}$ & $0.27^{* *}$ & -0.02 & $0.13^{* *}$ & $0.07^{*}$ & 0.02 & $-0.48^{* *}$ & $-0.32 * *$ & $-0.40 * *$ & $-0.46^{* *}$ & $0.59 * *$ & 1 & \\
\hline $\begin{array}{l}\text { 15. Sense of belonging to } \\
\text { University }\end{array}$ & $0.27^{* *}$ & $0.21^{* *}$ & $0.22 * *$ & $0.24^{* *}$ & 0.02 & 0.12 ** & $0.08^{* *}$ & 0.05 & $-0.39 * *$ & $-0.27^{* *}$ & $-0.34^{* *}$ & $-0.32^{* *}$ & $0.48^{* *}$ & $0.48^{* *}$ & 1 \\
\hline
\end{tabular}




\section{Discussion and Conclusions}

University students are in a dynamic transition period of growth and development that bridges childhood to adulthood, a period that is characterized by rapid, inter-related changes of mind and social relationships [70]. In the emerging and ever-changing pandemic context, universities have implemented a number of measures to slow the spread of the virus. So, new and different things have impacted university students during the coronavirus lockdown. Most students worldwide have been confined to their homes, where they are away from university learning resources, educators, and peers, and are attempting to learn remotely through textbooks or online resources. This new university life added more stress and requires, more independent decision-making, and different approaches to study and relationship.

On the subject, Akkermans and collogues [71] argued that the pandemic will be a career shock for young people and, highlighting the importance of the dynamic interplay between individual and contextual factors, argued that some psychosocial resources, among which are career competencies and employability, could make this career shock more manageable, thus helping students cope with the pandemic revolution more effectively. These developments indicate that more scholarly, along with policy-level and educational, attention is needed, to better to increase students' resources chances and career success.

On this in mind, our research highlighted the psychological impact of COVID-19 emergency outbreak on Italian university students.

Using Mental Health Continuum as a theoretical framework, we examined the relationships between mental well-being, internal health locus of control, risk perceptions, academic stress, student self-efficacy, satisfaction for the course degree, sense of belonging to university and social media information seeking, among a sample of Italian university students. We argued that, during the pandemic, exploring mental well-being is fundamental to support young individuals in making a smooth transition to the new idea of university.

Our findings mostly supported our hypotheses.

The COVID-19 pandemic was not been associated with significant psychological pressure in participants at our study, at least immediately. Levels of mental well-being appeared in line with normative values in Italian young adults [12], and levels of stress were not significantly higher than the one found in other student samples before the COVID-19 outbreak [43].

University students seemed to be still capable of finding some gratification from the university context. They also need to be a catalyst for necessary changes in the society, so that their graduates can be part of the transformation of society in the direction of sustainable development [72]. Based on our correlational results and, as demonstrated in previous studies $[56,63,73]$, academic efficacy beliefs, satisfaction and university sense of belonging could be considered as some relevant protective factors for students' mental health, suggesting that supportive university environments foster student flourishing. This is in line with our third hypothesis, since most experts believe that the COVID-19 disease will probably stay for an uncertain period of time, and its impacts on school, university and life have been, and will continue to be, tremendous [74]. Given the importance of human psychological and behavioral factors in managing pandemics, it is crucial to assess psychological and behavioral responses to the situation. Universities need to make the well-being of their students a priority. Helping students construct adequate psychological resources in life is a possible way to help them cope with further life challenges.

Furthermore, governments and universities around the globe should pay a closer attention to the role of risk perception at the individual level in more effectively managing policies and interventions around COVID-19. Our work highlighted as information seeking could contribute to higher levels of well-being in university students, verifying our second hypothesis. E-health information has the potential of providing people empowerment [75]. In public health communication, a growing body of research suggests that communicating health information is effective to improve preventive behaviors [22]. More specifically, we show that, in a challenging period, seeking pandemic-related 
information was associated with greater perception of risk: information could elicit intense worry and, in turn, lead to engagement in preventive actions [22]. As already mentioned, information seeking was positively associated with mental well-being: a higher level of psychological and social well-being resulted in students that more frequently sought information about the pandemic. Fostering the information seeking to get engaged in health prevention appears to be a crucial goal for educational and communication initiatives in a health emergency. However, future research should use multiple items to better capture the conceptual domain of this research construct. They are needed to better understand this variable's role and the specific characteristics of the information seeking, suggesting a more rigorous investigation of different digital media channels [76].

The present study was an attempt to investigate mental health in university students, in lockdown outbreak, within the Mental Health Continuum model [4]. To our knowledge, this is the first study that, following the classification proposed by Keyes [4], estimated the prevalence of mental well-being in students during the pandemic.

In line with previous studies in the general population [4,12,69,77-79], this work emphasized independent effects of mental health on a number of indicators of individual functioning in university students. The first hypothesis was verified because our findings supported the three-categories diagnosis of mental health proposed by Keyes [13]. They indicated that flourishing students functioned better than moderately healthy individuals, who in turn function better than languishing students in terms of measures of individual psychosocial assets. Flourishing is associated with desirable outcomes such as low academic stress, and enhanced students' efficacy beliefs, as well as satisfaction for their courses and sense of belonging to the university, deserving further attention in view of well-being promotion. Furthermore, being flourishing made students more aware of the actual risks of COVID-19 infection, in the period of maximum alert due to the pandemic.

Many studies analyzed the internal dimensions of locus of control in relation to different aspects of college and university students' daily life, such as academic achievement, self-esteem, academic procrastination, self-efficacy, optimism, self-concept, and sense of mastery [80]. Our results also indicated that flourishing is associated with a higher level of internal health related locus of control, suggesting that students with internal beliefs are more focused on their career and experience more well-being. Furthermore, results underlining the role of health-related locus of control for mental well-being, strengthening literature in this regard.

Overall, these results suggest a promising line for future research on the mental health continuum with students. They could be considered useful to realize training pathways to help the university students to improve their well-being in post-pandemic. The findings suggest that intervention studies should focus on particular groups and on raising their levels of mental well-being, to increase the effectiveness of educational initiatives dedicated to promoting preventive behaviors and responsible togetherness [81,82].

Although the results from this study suggest a promising line for future research on the Mental Health Continuum, the findings need to be considered in light of some limitations. First of all, caution is necessary, especially in placing too much emphasis on the current prevalence estimates. It is important to remember that the data were based on a non-probability, convenience sample. It is needed to identify whether this result can be reproduced in a representative sample. The sample was not balanced by gender. Therefore, future studies should investigate the specific and combined contribution of demographic variables for students. Then, conclusions are limited by cross-sectional data: the potential causal directions between variables need to be determined by longitudinal studies. The COVID-19 pandemic started in the Western countries in March and has lasted for 6 months, going through several stages, people's emotional responses and mental health level were waving during this period. The state of emergency is not over, and Italian students will soon face a period of alternation between online and face-to-face courses. So, further research is required to identify what predicts, enhances and maintains mental well-being in university students in the different phases of pandemic, to inform the development of new interventions targeting the complete mental health of students. 
The estimated correlations (and their directions) indicate the need to undertake further research to identify the determinants that may underlie the pathways for them. Furthermore, due to the limitations of self-report data, the findings are biased by students' perceptions. Self-report instruments also have the potential for social desirability bias. So, it will be important to use behavioral observations as well as self-reports, so as to minimize common method variance. Even though we need to consider this limitation, it is reasonable to think that this bias does not highly influence our data because anonymity was guaranteed in data collection [83].

Author Contributions: Conceptualization, V.C., D.C., A.R.D., and F.P.; methodology, V.C., D.C., and A.R.D.; software, V.C. and A.R.D.; formal analysis, V.C. and A.R.D.; investigation, V.C. and A.R.D.; data curation, V.C. and A.R.D.; writing—original draft preparation, V.C., D.C., and A.R.D.; writing-review and editing, V.C., D.C., and A.R.D.; supervision, V.C., D.C. and A.R.D.; project administration, V.C., D.C., A.R.D., and F.P. All authors have read and agreed to the published version of the manuscript.

Funding: This research received no external funding.

Conflicts of Interest: The authors declare no conflict of interest.

\section{References}

1. Italian Ministry of Health. (Section Dedicated to COVID-19). Available online: http://www.salute.gov.it/ portale/home.html (accessed on 22 June 2020).

2. Decree of the President of the Council of Ministers. Available online: https://www.esteri.it/mae/resource/ doc/2020/03/decreto_del_presidente_del_consiglio_dei_ministri_8_marzo_2020_en_rev_1.pdf (accessed on 22 June 2020).

3. Chambel, M.J.; Curral, L. Stress in academic life: Work characteristics as predictors of student well-being and performance. Appl. Psychol. Int. Rev. 2015, 54, 135-147. [CrossRef]

4. Keyes, C.L.M. Mental illness and/or mental health? Investigating axioms of the complete state model of health. J. Consult. Clin. Psychol. 2005, 73, 539-548. [CrossRef] [PubMed]

5. Suldo, S.; Thalji, A.; Ferron, J. Longitudinal academic outcomes predicted by early adolescents' subjective well-being, psychopathology, and mental health status yielded from a dual factor model. J. Posit. Psychol. 2011, 6, 17-30. [CrossRef]

6. Renshaw, T.L.; Cohen, A.S. Life satisfaction as a distinguishing indicator of college student functioning: Further validation of the two-continua model of mental health. Soc. Indic. Res. 2014, 117, 319-334. [CrossRef]

7. Huang, Y.; Zhao, N. Generalized anxiety disorder, depressive symptoms and sleep quality during COVID-19 epidemic in China: A web-based cross-sectional survey. 2020. [CrossRef]

8. Cellini, N.; Canale, N.; Mioni, G.; Costa, S. Changes in sleep pattern, sense of time and digital media use during COVID-19 lockdown in Italy. J. Sleep Res. 2020, 29, e13074. [CrossRef]

9. Al-Rabiaahab, A.; Temsahabc, M.H.; Al-Eyadhy, A.A.; Hasan, G.M.; Al-Zamil, F.; Al-Subaie, S.; Alsohime, F.; Jamal, A.; Alhaboob, A.; Al-Saadi, B.; et al. Middle East Respiratory Syndrome- Corona Virus (MERS-CoV) associated stress among medical students at a university teaching hospital in Saudi Arabia. J. Infect. Public Health 2020, 13, 687-691. [CrossRef]

10. Diener, E. Subjective well-being: The science of happiness and a proposal for a national index. Am. Psychol. 2000, 55, 34-43. [CrossRef]

11. Ryff, C.D.; Keyes, C.L.M. The structure of psychological well-being revisited. J. Pers. Soc. Psychol. 1995, 69, 719-727. [CrossRef]

12. Petrillo, G.; Capone, V.; Caso, D.; Keyes, C.L. The mental health continuum-short form (MHC-SF) as a measure of well-being in the Italian context. Soc. Indic. Res. 2015, 121, 291-312. [CrossRef]

13. Keyes, C.L.M. Promoting and protecting mental health as flourishing: A complementary strategy for improving national mental health. Am. Psychol. 2007, 62, 95-108. [CrossRef] [PubMed]

14. Keyes, C.L.M. The mental health continuum: From languishing to flourishing in life. J. Health Soc. Behav. 2002, 43, 207-222. [CrossRef] [PubMed]

15. Graffigna, G.; Barello, S. Measuring Italian Citizens' engagement in the first wave of the COVID-19 pandemic containment measures a cross-sectional study. medRxiv 2020, preprint. [CrossRef] 
16. Caso, D.; Carfora, V.; Starace, C.; Conner, M. Key Factors Influencing Italian Mothers' Intention to Vaccinate Sons against HPV: The Influence of Trust in Health Authorities, Anticipated Regret and Past Behaviour. Sustainability 2019, 11, 6879. [CrossRef]

17. Young, S.; Oppenheimer, D.M. Effect of communication strategy on personal risk perception and treatment adherence intentions. Psychol. Health Med. 2009, 14, 430-442. [CrossRef]

18. Hoda, J. Identification of information types and sources by the public for promoting awareness of Middle East respiratory syndrome coronavirus in Saudi Arabia. Health Educ. Res. 2016, 31, 12-23. [CrossRef]

19. Razak, A.A.; Mansor, N. Changing Awareness about Health Behavior: A Study among Young Instagram Users. J. Appl. Behav. Sci. 2020, 15, 19-33.

20. Procentese, F.; Gatti, F.; Di Napoli, I. Families and social media use: The role of parents' perceptions about social media impact on family systems in the relationship between family collective efficacy and open communication. Int. J. Environ Res. Public Health 2019, 16, 5006. [CrossRef]

21. Zakaria, N.; Mustaffa, C.S. Source Credibility, Risk Communication and Well-being: A Conceptual Framework. Procedia Soc. Behav. Sci. 2014, 155, 178-183. [CrossRef]

22. Liu, L.P. COVID-19 Information Seeking on Digital Media and Preventive Behaviors: The Mediation Role of Worry. Cyberpsychol. Behav. Soc. Netw. 2020. [CrossRef]

23. Brug, J.; Aro, A.R.; Richardus, J.H. Risk perceptions and behaviour: Towards pandemic control of emerging infectious diseases: International research on risk perception in the control of emerging infectious diseases. Int. J. Behav. Med. 2009, 16, 3. [CrossRef] [PubMed]

24. Slovic, P. Smoking: Risk, Perception, and Policy; Sage Publications: London, UK, 2001.

25. Ibuka, Y.; Chapman, G.B.; Meyers, L.A.; Li, M.; Galvani, A.P. The dynamics of risk perceptions and precautionary behavior in response to 2009 (H1N1) pandemic influenza. BMC Infect. Dis. 2010, 10, 296. [CrossRef] [PubMed]

26. Janz, N.K.; Becker, M.H. The health belief model: A decade later. Health Educ. Q. 1984, 11, 1-47. [CrossRef] [PubMed]

27. Lindell, M.K.; Perry, R.W. The protective action decision model: Theoretical modifications and additional evidence. Risk Anal. 2012, 32, 616-632. [CrossRef]

28. Wei, J.; Zhao, D.; Liang, L. Estimating the growth models of news stories on disasters. J. Am. Soc. Inf. Sci. Technol. 2009, 60, 1741-1755. [CrossRef]

29. Wei, J.; Zhao, M.; Wang, F.; Cheng, P.; Zhao, D. An Empirical Study of the Volkswagen Crisis in China: Customers' Information Processing and Behavioral Intentions. Risk Anal. 2016, 36, 114-129. [CrossRef]

30. Seale, H.; McLaws. M.L.; Heywood, A.E.; Ward, K.F.; Lowbridge, C.P.; Van, D.; Gralton, J.; MacIntyre, C.R. The community's attitude towards swine flu and pandemic influenza. Med. J. Aust. 2009, 191, 267-269. [CrossRef]

31. Wang, F.; Wei, J.; Huang, S.K.; Lindell, M.K.; Ge, Y.; Wei, H.L. Public reactions to the 2013 Chinese H7N9 Influenza outbreak: Perceptions of risk, stakeholders, and protective actions. J. Risk Res. 2018, 21, 809-833. [CrossRef]

32. Fraser, S.; Lagacé, M.; Bongué, B.; Ndeye, N.; Guyot, J.; Bechard, L.; Garcia, L.; Taler, V.; CCNA Social Inclusion and Stigma Working Group; Adam, S.; et al. Ageism and COVID-19: What does our society's response say about us? Age Ageing 2020, 1-4. [CrossRef]

33. Gerhold, L. COVID-19: Risk perception and Coping strategies. PsyArXiv 2020. [CrossRef]

34. Wallston, K.A.; Wallston, B.S.; De Vellis, R.F. Development of the Multidimensional Health Locus of Control (MHLC) Scale. Health Educ. Monog. 1978, 6, 160-170. [CrossRef] [PubMed]

35. Donizzetti, A.R.; Petrillo, G. Health Locus of Control Scale per adolescenti: Uno studio di validazione. Psicol. Della Salut. 2011, 2, 85-101. [CrossRef]

36. Donizzetti, A.R.; Petrillo, G. Validazione della versione per adulti dell'Health Locus of Control Scale. Psicol. Della Salut. 2015, 3, 126-142. [CrossRef]

37. Strickland, B.R. Internal-external expectancies and health related behaviours. J. Consult. Clin. Psychol. 1978, 46, 1192-1211. [CrossRef]

38. Steptoe, A.; Wardle, J.; Vinck, J. Personality and attitudinal correlates of healthy and unhealthy lifestyles un young adults. Health Psychol. 1994, 9, 331-343. [CrossRef]

39. Petrillo, G.; Donizzetti, A.R. Credenze illusorie sulla salute in adolescenza: Validazione di uno strumento di rilevazione. G. Ital. Psicol. 2012, 2, 407-434. [CrossRef] 
40. Norris, F.H. Frequency and structure of precautionary behaviour in the domain of hazard. Preparedness, crime prevention, vehicular safety, and health maintenance. Health Psychol. 1997, 16, 566-575. [CrossRef]

41. Schwarzer, R.; Fuchs, R. Self-efficacy and health behaviours. In Predicting Health Behaviour: Research and Practice with Social Cognition Models; Conner, M., Norman, P., Eds.; Open University Press: Berlin, Germany, 1996; pp. 163-196.

42. Dunning, A.; Pownall, M. Dispositional and situational attribution of COVID-19 risk: A content analysis of response typology (version: 1). PsyArXiv 2020. [CrossRef]

43. Owen, M.S.; Kavanagh, P.S.; Dollard, M.F. An integrated model of work-study conflict and work-study facilitation. J. Career Dev. 2018, 45, 504-517. [CrossRef]

44. Lazarus, R.S.; Folkman, S. Stress, Appraisal, and Coping; Springer Publishing: New York, NY, USA, 1984.

45. Tapia, A.; Guajardo, C.; Quintanilla, A. Estiloscognitivosen el bienestar y el estrés. Rev. Mex. Psicol. 2008, 388-389.

46. Tinglin, S.A. The Perceptions of Stress in Mature Female Nurses Returning to School for Graduate Studies; D'Youville College: Buffalo, NY, USA, 2006.

47. Elliot, A.J.; Shell, M.M.; Henry, K.B.; Maeir, M.A. Achievement goals, performance contingencies, and performance attainment: An experimental test. J. Educ. Psychol. 2005, 97, 630-640. [CrossRef]

48. Kurebayashi, L.F.S.; Do Prado, J.M.; Da Silva, M.J.P. Correlations between stress and anxiety levels in nursing students. J. Nurs. Educ. Pract. 2012, 2, 128. [CrossRef]

49. Nelwati, D.; Mckenna, L.; Plummer, V. Indonesian student nurses' perceptions of stress in clinical learning: A phenomenological study. J. Nurs. Educ. Pract. 2012, 3, 56-65. [CrossRef]

50. Huang, N.; Qiu, S.; Alizadeh, A.; Wu, H. How Incivility and Academic Stress Influence Psychological Health among College Students: The Moderating Role of Gratitude. Int. J. Environ. Res. Public Health. 2020, 17, 3237. [CrossRef] [PubMed]

51. Pfeiffer, D. Academic and Environmental Stress among Undergraduate and Graduate College Students: A Literature Review. Master's Thesis, University of Wisconsin-Stout Menomonee, Menomonie, WI, USA, 2001; Unpublished.

52. Mancini, J.; Lavecchia, C.; Clegg, R. Graduate nursing students and stress. J. Nurs. Educ. 1983, 22, 329-334. [PubMed]

53. Salanova, M.; Peiró, J.M.; Schaufeli, W.B. Self-efficacy specificity and burnout among information technology workers: An extension of the job demand-control model. Eur. J. Work Organ. Psychol. 2002, 11, 1-25. [CrossRef]

54. Bandura, A. Self-Efficacy: The Exercise of Control; Freeman: New York, NY, USA, 1977.

55. Bandura, A. Self-efficacy: Toward a unifying theory of behavioral change. Psychol. Rev. 1997, 84, 191-215. [CrossRef]

56. Capone, V. Il work-study conflict degli student universitari: Quali relazioni con il benessere? Psicol. Della Salut. 2018, 3, 131-144. [CrossRef]

57. Guglielmi, D.; Paplomatas, A.; Simbula, S.; Depolo, M. Prevenzioned ello stress lavoro correlato: Validazione di uno strumento per la valutazione dei rischi psicosociali nella scuola. Psicol. Della Salut. 2011, 3, 53-74. [CrossRef]

58. Stetz, T.A.; Stetz, M.C.; Bliese, P.D. The importance of self-efficacy in the moderating effects of social support on stressor-strain relationships. Work Stress 2006, 20, 49-59. [CrossRef]

59. Simbula, S.; Guglielmi, D.; Schaufeli, W.B. A three wave study on job resources, self-efficacy and work engagement among Italian school teachers. Eur. J. Work Organ. Psychol. 2011, 20, 285-305. [CrossRef]

60. Fisher, A.T.; Sonn, C.C.; Bishop, B. Psychological Sense of Community: Research, Applications, and Implications; Plenum Press: New York, NY, USA, 2002.

61. Cicognani, E.; Pirini, C.; Keyes, C.; Joshanloo, M.; Rostami, R.; Nosratabadi, M. Social Participation, Sense of Community and Social Well Being: A Study on American, Italian and Iranian University Students. Soc. Indic. Res. 2008, 89, 97-112. [CrossRef]

62. Petrillo, G.; Capone, V.; Donizzetti, A.R. Classroom Sense of Community Scale: Validation of a Self-Report Measure for Adolescents. J. Community Psychol. 2016, 44, 399-409. [CrossRef]

63. Capone, V.; Donizzetti, A.R.; Petrillo, G. Collective efficacy, school sense of community, school climate and perceptions of justice for students' well-being. J. Community Psychol. 2018, 46, 374-382. [CrossRef] 
64. Lo Presti, A.; Capone, V.; Dell'Aversana, A.; Akkermans, J. Career Competencies and Career Success: On the Roles of Employability Activities and Academic Satisfaction during the School-to Work Transition. J. Career Dev. in press.

65. Hewson, C.; Vogel, C.; Laurent, D. Internet Research Methods, 2nd ed.; Sage: London, UK, 2016.

66. Kirby, P.G.; Biever, J.L.; Martinez, I.G.; Gomez, J.P. Adults Returning to School: The Impact on Family and Work. J. Psychol. 2004, 138, 65-76. [CrossRef]

67. Capone, V.; Petrillo, G.; Romano, A. La soddisfazione lavorativa e per la vita di medici e infermieri ospedalieri: Relazioni con il senso di appartenenza all'azienda ospedaliera, le percezioni di efficacia collettiva e il sostegno sociale percepito. Psicol. Della Salut. 2013, 3, 115-130. [CrossRef]

68. Bedewy, D.; Gabriel, A. Examining perceptions of academic stress and its sources among university students: The Perception of Academic Stress Scale. Health Psychol. Open 2015, 2. [CrossRef]

69. Keyes, C.L.M. Mental health in adolescence: Is America's youth flourishing? Am. J. Orthopsychiat. 2006, 76, 395-402. [CrossRef]

70. World Health Organization. The World Health Organization Report 1997: Conquering Suffering, Enriching Humanity; World Health Organization: Geneva, Switzerland, 1997.

71. Akkermans, J.; Richardson, J.; Kraimer, M. The Covid-19 crisis as a career shock: Implications for careers and vocational behavior. J. Vocat. Behav. 2018, 119, 103434. [CrossRef]

72. Bucea-Manea-Țoniş, R.; Bucea-Manea-T,oniş, R.; Simion, V.E.; Ilic, D.; Braicu, C.; Manea, N. Sustainability in Higher Education: The Relationship between Work-Life Balance and XR E-Learning Facilities. Sustainability 2020, 12, 5872. [CrossRef]

73. Caprara, G.B.; Barbaranelli, C.; Steca, P.; Malone, P.S. Teachers' self-efficacy beliefs as determinants of job satisfaction and students' academic achievement: A study at the school level. J. Sch. Psychol. 2006, 44, 473-490. [CrossRef]

74. Paton, J. When, and How, Does the Coronavirus Pandemic End? Bloomberg. Available online: https: //www.bloombergquint.com/quicktakes/when-andhow-does-the-coronavirus-pandemic-end-quicktake (accessed on 3 April 2020).

75. Suziedelyte, A. How Does Searching for Health In-formation on the Internet Affect Individuals' Demand for Health Care Services? Soc. Sci. Med. 2012, 75, 28-35. [CrossRef] [PubMed]

76. Westerman, D.; Van Der Heide, B.; Klein, K.A.; Walther, J.B. How do people really seek information about others? Information seeking across Internet and traditional communication channels. J. Comput. Mediat. Commun. 2008, 13, 751-767. [CrossRef]

77. Joshanloo, M.; Capone, V.; Petrillo, G.; Caso, D. Discriminant Validity of Hedonic, Social, and Psychological Well-being in two Italian Samples. Pers. Individ. Diff. 2017, 109, 23-27. [CrossRef]

78. Petrillo, G.; Caso, D.; Capone, V. Un'applicazione del Mental Health Continuum di Keyes al contesto italiano: Benessere e malessere in giovani e adulti. Psicol. Della Salut. 2014, 2, 159-181. [CrossRef]

79. Capone, V.; Petrillo, G. Mental health in teachers: Relationships with job satisfaction, efficacy beliefs, burnout and depression. Curr. Psychol. 2018. [CrossRef]

80. Sagone, E.; De Caroli. M.E.A Correlational Study on Dispositional Resilience, Psychological Well-being, and Coping Strategies in University Students. Am. Educ. Res. J. 2014, 2, 463-471. [CrossRef]

81. Procentese, F.; Gatti, F. Senso di convivenza responsabile: Quale ruolo nella relazione tra partecipazione e benessere sociale? [Sense of responsible coexistence: What role in the relationship between participation and social well-being?]. Psicol. Soc. 2019, 14, 405-426. [CrossRef]

82. Procentese, F.; Gatti, F.; Falanga, A. Sense of responsible togetherness, sense of community and participation: Looking at the relationships in a university campus. Hum. Aff. 2019, 29, 247-263. [CrossRef]

83. Roccato, M. L'inchiesta e IL Sondaggio; Bologna: Mulino, IL, USA, 2006.

(C) 2020 by the authors. Licensee MDPI, Basel, Switzerland. This article is an open access article distributed under the terms and conditions of the Creative Commons Attribution (CC BY) license (http://creativecommons.org/licenses/by/4.0/). 